\title{
试析水利施工管理中存在的问题及改进措施
}

\author{
张尧 晏宁
}

陕西省汉中市南郑区水土保持工作站

DOI:10.32629/hwr.v4i3.2802

[摘 要] 目前水利工程建设阶段仍存在很多问题需要解决,管理就是其中较为重要的一项,本文对水利工程施工管理中存在的问题进行了分析 探讨,并结合笔者自身经验提出相应的改进措施, 以提升水利工程质量。

[关键词] 水利工程; 施工管理; 改进措施

随着社会的快速发展, 水利工程建设也逐渐向机械化方向迈进, 但由 于水利工程施工中的影响因素较多, 工程作业存在较多问题, 施工管理就 是其中一项, 其对于水利工程的施工质量有着较大影响, 相关人员需结合 实际情况制定合理的解决措施, 以推动水利行业的稳定发展。

\section{1 水利施工管理重要性}

首先, 水利工程施工管理是对施工质量、进度及成本实行科学管控的 重要措施, 加大对施工管理的重视力度, 引进先进技术工艺, 可有效加强水 利工程建设效果, 促进水利行业的健康发展。其次, 水利工程建设中存在的 影响因素较多, 如材料影响、人工影响等, 施工管理可对这些影响因素进行 科学管控, 从而减少不安全现象的产生, 提高施工作业的效率, 实现经济效 益的最大化。最后, 施工管理的改善可加强安全管理, 合理控制风险隐患, 促进工程建设作业的顺利开展。开展施工管理时, 需要对现场资料及实际 情况予以勘察, 并结合资料内容进行合理规划, 从而避免各项问题的产生, 以改进水利工程建设质量。

\section{2 水利施工管理存在的问题}

2. 1 安全问题

水利工程施工多是野外作业, 环境较为复杂, 存在的安全隐患较多, 如 果不能对其实施科学处理, 则很容易增加水利工程建设的危险性, 威胁人 员及财产安全。水利工程施工管理中存在的安全问题可归纳为以下几种:

一是施工安全管理表面化现象严重, 安全管理制度落实不到位, 缺少 科学监管方案, 导致安全问题频生, 降低水利工程的建设质量。二是施工安 全管理人员缺少专业性, 且一些人员是从其他部门借调过来的, 对安全管 理重视力度不足, 安全管理工作不到位, 进而降低水利工程施工质量。三是 施工安全技术投入不足, 安全管理要求不明确, 如此就增加了安全隐患的 出现概率。

\section{2 质量问题}

质量一直都是水利工程管理的重点内容, 一旦出现质量问题, 不仅会 影响水利工程建设效果, 造成经济的损耗, 还会给人民及社会稳定带来严 重影响。水利工程施工中, 质量问题产生的主要原因为: 施工监管人员并 未按照规定要求开展质量监督和检查工作, 存在的质量问题得不到及时解 决和处理; 施工单位管理不到位、竣工验收工作不合格, 质量问题堆积严 重, 影响后续使用安全, 引发安全事故。

2. 3 成本问题

成本控制一直都是水利行业发展中重点关注的内容, 其需要在保证工 程质量的基础上, 降低成本损耗, 增大项目经济效益。不过目前在水利工程 成本控制中, 由于市场竞争的日益激烈, 成本控制及风险管控难度增加, 造 成的资金方面的消耗也在不断提升; 工程评估标准不统一, 设计内容与实 际工作存在较大差异; 受传统工作理念的影响, 成本及资源浪费现象普遍; 成本控制存在形式主义, 实际控制效果不理想。

\section{3 水利工程施工管理的改进措施}

3.1 加强成本支出的管控

施工成本控制贯穿在施工各环节中, 且与施工质量有着紧密联系。为 此, 在施工成本控制中, 应结合各环节施工内容及要求, 有针对性的制定施 工成本控制方案, 并采取不同的管理措施和方法, 降低成本损耗。另外, 施 工成本控制还可减少施工变更, 促进工程的有序开展。所以在实际作业中, 管理者需制定明确的成本控制目标, 编辑详细的成本控制方案, 并在合同 中对因成本损耗而造成不良影响的行为给与一定的处罚, 加大人员对施工 成本管理的重视力度, 确保工程按照设计要求有序开展。

3. 2 强化施工质量管理

施工质量管理可分为材料管理、设备管理及技术工艺管理三部分内容。 在材料管理中, 需要加大材料采购及验收环节的管理力度, 保证材料质量符合 施工要求, 禁止不合格材料的混入, 强化施工效果。在设备管理上, 需要对设备 型号、性能实行科学检查, 按照工作要求调试设备参数, 增强使用安全性。同 时要定期做好设备检修和维护工作, 降低故障问题带来的经济损失。在施工工 艺控制上, 需按照施工方案内容科学选用工艺技术, 使工程按照设定的指标要 求开展。在施工工艺选择前, 要对方案内容展开严格审查, 增强方案的细致性、 合理性, 以免削弱施工工艺技术的落实效果, 造成不必要的经济损失。

3. 3做好安全管理

安全管理作为水利工程施工中较为重要的内容, 加大人员安全管理重 视力度, 深化安全意识, 对于水利工程质量及经济性有着显著作用。在安全 管理中, 首先要完善安全管理制度, 构建安全管理体系, 确保安全管理工作 的落实有据可循, 有法可依。同时成立专门的安全监督部门, 且配备专业人 员, 确保工作的有效开展。

其次, 做好安全教育培训, 深化工作人员安全意识, 且定期进行安全知 识的更新和讲解, 增强安全管理的有效性。

最后, 定期开展安全检查。安全检查可对施工中存在的安全隐患及问 题予以及时掌握和处理, 且能够快速生成应急预案, 有效控制安全问题, 避 免危险事故的发生。对于危险区域, 可设置安全警示标示, 提醒工作人员, 以营造良好的施工环境。

\section{4 结语}

水利工程施工管理是提高水利工程建设质量, 增加水利建设经济效益 的重要手段。管理者需加强对其重视, 且从质量、成本、安全多方面展开 管控, 以此推动水利工程的顺利完工。

\section{[参考文献]}

[1]杜勇.水利水电工程施工管理分析[J].建材与装饰,2017,(11):58.

[2]高永民,侯丽君,杨杰.水利水电工程施工安全管理与控制分析 [J]. 工程技术研究,2019,4(09):141-142.

[3]魏利.水利水电工程管理浅析[J].建材与装饰,2019,(16):294-295. 